\title{
Healthy Eating for Elders: Food Storage Guide ${ }^{1}$
}

Jennifer Hillan ${ }^{2}$

If you don't shop for groceries often, you probably try to buy food that will last

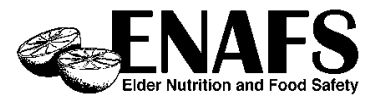

until your next trip to the store. To help you learn how much to buy, here are storage guidelines for some perishable foods. Tips: Store fruits and vegetables (except potatoes and tomatoes) in the crisper drawer of your refrigerator, and keep your refrigerator below 40E F. Store potatoes and tomatoes at room temperature.
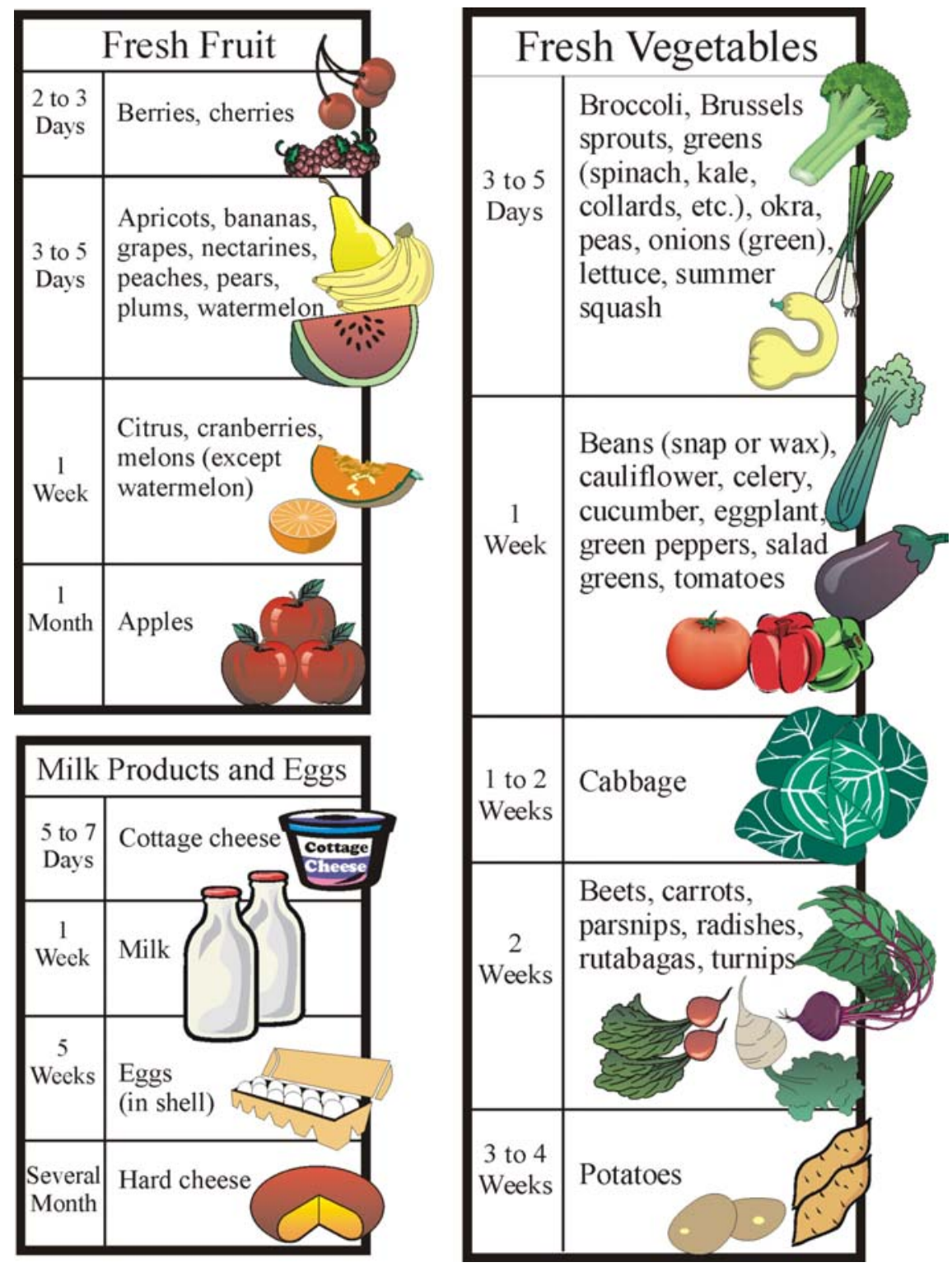

1. This is document FCS 8695 -ENG, one in a series of the Department of Family, Youth and Community Sciences, Florida Cooperative Extension Service, Institute of Food and Agricultural Sciences, University of Florida, Gainesville, FL 32611. Publication date: February 2005. This leaflet was developed with funding from the Florida Department of Elder Affairs in partnership with state, county, and local agencies. Please visit the EDIS Web site at http://edis.ifas.ufl.edu

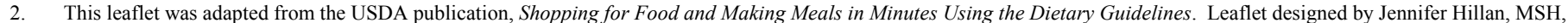
RD, LD/N, former ENAFS nutrition educator/trainer and Joyce Lottinville, and reviewed by Linda B. Bobroff, Ph.D., RD, LD/N, professor, and Leigh Ann Martin, MESS, former ENAFS project coordinator, Department of Family, Youth and Community Sciences, Institute of Food and Agricultural Sciences, University of Florida, Gainesville, FL 32611.

The Institute of Food and Agricultural Sciences is an equal opportunity/affirmative action employer authorized to provide research, educational information and other services only to individuals and institutions that function without regard to race, color, sex, age, handicap, or national origin. For information on obtaining other extension publications, contact your county Cooperative Extension Service office. Florida Cooperative Extension Service / Institute of Food and Agricultural Sciences / University of Florida / Larry R. Arrington, Dean 